\title{
Scales for pain assessment in cervical dentin hypersensitivity: a comparative study
}

\section{Escalas para avaliação da dor na hipersensibilidade dentinária cervical: um estudo comparativo}

\author{
Bethânia Lara Silveira Freitas ${ }^{1}$ (D), Marina de Souza Pinto ${ }^{1}$ (D), Evandro Silveira de Oliveira' $\mathbb{I D}^{\text {, }}$ \\ Dhelfeson Willya Douglas-de-Oliveira' (D), Endi Lanza Galvão' (D), Patricia Furtado Gonçalves ${ }^{(D)}$, \\ Olga Dumont Flecha' ${ }^{1}$, Paulo Messias de Oliveira Filho' ${ }^{1}$ \\ ${ }^{1}$ Departamento de Odontologia, Universidade Federal dos Vales do Jequitinhonha e Mucuri (UFVJM), Diamantina (MG), Brasil.
}

How to cite: Freitas BLS, Pinto MS, Oliveira ES, Douglas-de-Oliveira DW, Galvão EL, Gonçalves PF, et al. Scales for pain assessment in cervical dentin hypersensitivity: a comparative study. Cad Saúde Colet, 2020;28(2):271-277. https://doi. org/10.1590/1414-462X202000020372

\begin{abstract}
Background: Currently, different pain scales are used extensively to measure clinical pain, especially in dental practice. Objective: This study aims to compare pain scales used in clinical research and dental practice, identifying the easiest to understand by patients with Cervical Dentin Hypersensitivity. Method: Seventy-four patients with Cervical Dentin Hypersensitivity were stimulated by a thermic test of the sensitive tooth, followed by application of different pain measurement scales (Visual Analogue Scale, Faces Pain Scales, Numeric Rating Scale, and Verbal Rating Scale) and by a questionnaire to evaluate the patient's perception regarding the ease of understanding scales. The statistic tests used were the Wilcoxon, Spearman correlation, and Chi-Square tests. Results: The results founded a strong positive correlation between the scales $(r=0.798$ to $0.960 p<0.001)$. The was easiest scale to understand according to the patients was the Verbal Rating Scale (52.7\%). Conclusion: The pain measurement scales evaluated provide similar information about pain reported in the Cervical Dentin Hypersensitivity allowing the comparison between studies that used them to measure pain. The affinity of the patient with the pain scale can guide the clinical dental practice in the different levels of health care.
\end{abstract}

Keywords: dentin hypersensitivity; dentin hypersensitivity assessment; pain measurement; pain scale.

\section{Resumo}

Introdução: Atualmente, diferentes escalas têm sido utilizadas para medir a dor no contexto clínico, especialmente na prática odontológica. Objetivo: O objetivo deste estudo foi comparar as escalas de dor comumente utilizadas em pesquisas clínicas e na prática clínica odontológica, identificando as mais fáceis de serem compreendidas pelos pacientes com hipersensibilidade dentinária cervical. Método: Setenta e quatro pacientes com hipersensibilidade dentinária cervical foram estimulados por um teste térmico para avaliação do dente sensível, seguido pela aplicação de diferentes escalas para avaliação de dor (Escala Visual Analógica, Faces de Dor, Escala Numérica e Escala Verbal) e de um questionário complementar para avaliar a percepção do paciente em relação à facilidade de compreensão das escalas. Os resultados foram submetidos aos testes de correlação de Wilcoxon, Spearman e Qui-Quadrado. Resultados: Uma forte correlação positiva foi encontrada entre as quatro escalas avaliadas $(r=0,798$ a 0,960; $p<0,001)$. De acordo com os pacientes, a escala de mais fácil compreensão foi a Escala Verbal (52,7\%). Conclusão: As escalas para mensuração da dor fornecem informações semelhantes sobre a dor relatada na hipersensibilidade dentinária cervical. A afinidade do paciente pela escala de dor pode direcionar a escolha da escala a ser utilizada na prática clínica odontológica nos diversos níveis de atenção à saúde.

Palavras-chave: sensibilidade da dentina; avaliação da hipersensibilidade dentinária; medição da dor; escala de dor.

This is an Open Access article distributed under the terms of the Creative Commons Attribution License, which permits unrestricted use, distribution, and reproduction in any medium, provided the original work is properly cited.
Study carried out at Universidade Federal dos Vales do Jequitinhonha e Mucuri (UFVJM) - Diamantina (MG), Brasil. Correspondence: Endi Lanza Galvão. E-mail: endilanza@yahoo.com.br

Financial support: This study was financed in part by the Coordenação de Aperfeiçoamento de Pessoal de Nível Superior Brasil (CAPES) - Finance Code 001.

Conflict of interests: nothing to declare.

Received on: Aug. 17, 2018. Accepted on: June 19, 2019 


\section{INTRODUCTION}

Pain is a sensory and emotional experience of discomfort, presenting a subjective and individual nature. It can be influenced by emotional, cultural, or physical factors ${ }^{1,2}$. The difficulty in pain measurement is related to the patient's individuality and comprehensiveness ${ }^{3}$. The subjective nature of pain is one of the most measured components both in research and clinical practice ${ }^{4}$.

Numerous tools used to measure pain are described in the literature, such as questionnaires and physiological responses ${ }^{1}$. In recent years, pain scales have gained a greater proportion in research and clinical settings such as the Visual Analogue Scale (VAS), Face Pain Scale (FPS), Numerical Rating Scale (NRS), and Verbal Rating Scale (VRS) ${ }^{5-8}$. These scales aim to measure, qualify, or evaluate the patient's behavior when facing painful experiences ${ }^{9}$. Scales for pain assessment are useful in the fields of temporomandibular disorders ${ }^{3}$, pediatric dentistry ${ }^{10}$, anesthetic techniques ${ }^{11}$, and cervical dentin hypersensitivity $(\mathrm{CDH})^{6}$.

$\mathrm{CDH}$ is a relatively common problem frequently found in the adult population worldwide. One in six patients' presents this manifestation, and acute pain, of short duration and variable intensity characterizes it, that can be provoked mainly by tactile, chemical, or thermal stimuli 8,12 . The pain caused by $\mathrm{CDH}$ hinders the patient to perform everyday tasks, such as maintenance of oral hygiene, feeding, and communication ${ }^{13}$. Toothaches are the main causes of impairment of daily activities, difficulty in chewing food and sleeping. They present a strong social and psychological impact that can affect the quality of life ${ }^{14-16}$.

The use of pain assessment scales can provide information about the severity, duration, tolerance, and description of $\mathrm{CDH}$-related pain, allowing researchers and clinicians to better understand not only the condition of $\mathrm{CDH}$-related pain, but also other associated pain conditions and still evaluate the efficacy of treatment strategies ${ }^{4}$. Moreover, these easy-to-access and low-cost tools can track CDH for early intervention.

In clinical research, the use of scales for pain assessment certainly contributes to greater methodological standardization. In the literature, several scales are mentioned, and knowing the correlation between them is important to compare different studies. Another issue is the perception of the patient regarding the ease of understanding of the scales since research with this approach in the CDH-related pain measurement is scarce.

Thus, the present study aims to compare VAS, FPS, NRS, and VRS pain scales used in clinical research, correlating them, and identifying the easiest one to the patients understand with CDH .

\section{METHOD}

This cross-sectional study was carried out in Diamantina, Minas Gerais, at the periodontics clinic of the Department of Dentistry of UFVJM, from August 2016 to February 2017, using a convenience sample of patients.

The sample size was calculated for the comparison of means ${ }^{17}$. The standard deviation of sensitivity obtained on a visual analog scale $(2.23 \mathrm{~mm})^{18}$ was considered and the difference to be detected between groups was stipulated in $1 \mathrm{~mm}$, with a level of significance set at $5 \%$ and power of $95 \%$. It was determined that 65 participants would be needed, and $15 \%$ were added to prevent eventual losses.

The Human Research Ethics Committee of UFVJM approved the study [Universidade Federal dos Vales do Jequitinhonha e Mucuri, $\left.n^{\circ} 2102360\right]$. The sample was obtained from the UFVJM database and patients with dentin hypersensitivity who accepted the invitation to participate and signed the informed consent form.

We included people over the age of 18 who had CDH (individuals with a response $\geq 1$ on the Schiff scale) and agreed to participate in the study by signing a free and informed consent term. We excluded from the study participants who were using NSAIDs (non-steroidal anti-inflammatory drugs), desensitizing pastes, patients who had restored or decayed sensitive teeth, and undergoing dental bleaching for 15 days before clinical examination.

The procedures consisted of counseling patients on the use of pain measurement scales, followed by stimulation of the tooth with $\mathrm{CDH}$ using thermal stimulation ${ }^{19}$, application of 
pain measurement scales, and a questionnaire, respectively. The researchers were previously calibrated for the application of the tests (Kappa> 0.7).

A cotton-tipped flexible shaft was soaked in ice water (temperature $3^{\circ} \mathrm{C}$ ) and placed in contact with the cervical vestibular surface of upper premolars ${ }^{20}$ for 5 seconds, and the most sensitive tooth was chosen for evaluation. After the stimulus, the patient was instructed to mark the intensity of the pain in the scales according to the following order, previously raffled: VAS, NRS, FPS, and VRS (Figure 1). The VAS is presented as a $10 \mathrm{~cm}$ line, anchored by verbal descriptors, with the expressions "no pain" and "worst pain" at the extremities. The patient was instructed to mark in this line the intensity of the perceived pain. The NRS is composed of an 11-point scale, in which individuals are asked to indicate the number they value for their 0-10 pain, where 0 means no pain and 10 the most severe pain ${ }^{21}$. FPS relies on facial expression drawings to illustrate each spectrum of pain intensity. It is composed of 6 faces drawings showing gradual increases of discomfort and the patient is asked to choose, in the set of faces, the one that best adapts to his affective state ${ }^{22}$.VRS comprises a list of adjectives used to denote increasing pain intensities, such as no pain, mild pain, moderate pain, and severe pain.

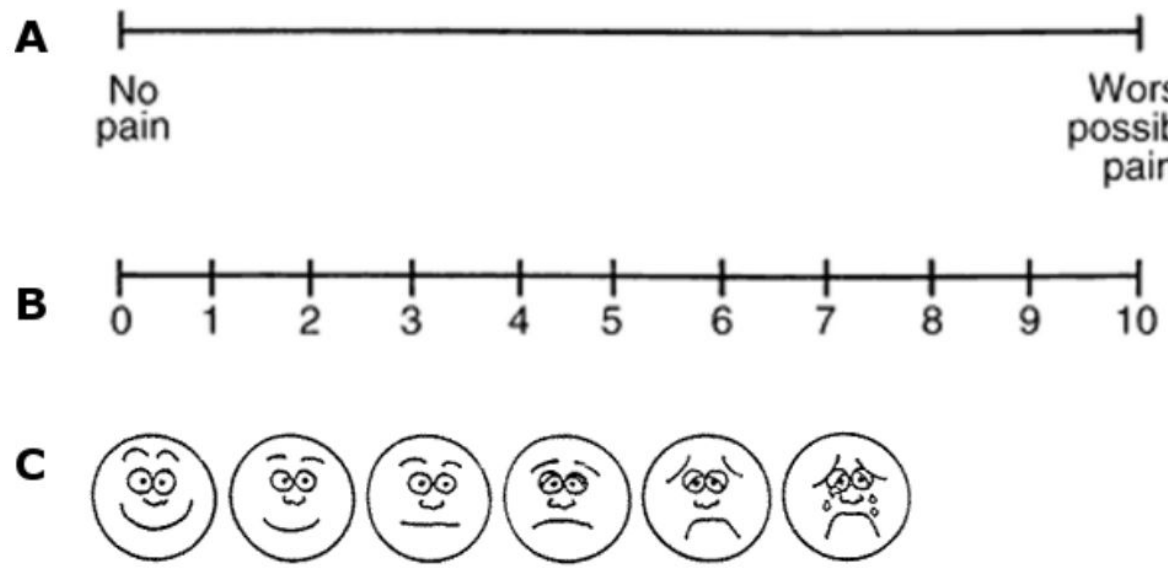

\section{None Mild Moderate Severe}

Figure 1. Pain rating scales used. A) Visual analogue scale B) Numerical scale rating C) Face rating scale D) Verbal rating scale. Note: Reprinted from "Briggs Healthcare Wong-Baker Faces Pain Rating Scale Card"23.

Three questions were then asked the patients in the following order: 1) Regarding the scales used to assess the degree of your dentin hypersensitivity, which one did you find easier to understand? 2) Concerning the scales used to assess the degree of your dentin hypersensitivity, which one did you find most difficult to understand? 3) Concerning the scales used to assess the degree of your dentin hypersensitivity, what was your preference? Why?

Afterward, all study participants underwent oral health assessment, desensitizing therapy ${ }^{20}$ on teeth with $\mathrm{CDH}$, and oral hygiene orientation.

Data analysis was performed in IBM SPSS Statistics Version 22.0 software. Descriptive statistics analyzes obtained the mean, absolute and relative frequencies of the data. The normality of the data was verified by the Kolmogorov-Smirnov test. The drawing faces expressed in the FPS scale were converted to numerical scores, according to each face, in a 6-point Likert scale (0-5) and the descriptors representing four different pain intensities in the VRS scale was recategorized using a 4 -point Likert scale $(0=$ none, $1=$ mild, $2=$ moderate, $3=$ severe). Then, the Spearman correlation test evaluated the correlation between scales. The patient perception regarding the understanding of different types of pain scales (quantitative or categorical), according to age and gender was evaluated by the Chi-Square tests. The level of significance was set at $5 \%(p<0.05)$. 


\section{RESULTS}

The population was composed of 74 adult patients with $\mathrm{CDH}$, ranging from 18 to 55 years old, with a mean age of 23.9 years old, 16 male (21.6\%), and 58 female (78.4) patients.

There was a statistically significant correlation between all scales (VAS, FPS, NRS, and VRS) $(p<0.001)$. The correlations coefficient ranged from 0.798 to 0.960 (Table 1).

Table 1. Correlation between different pain scales - Diamantina, Minas Gerais, 2016 a 2017

\begin{tabular}{|c|c|c|c|c|c|c|c|c|}
\hline & \multicolumn{2}{|c|}{$\begin{array}{l}\text { Visual analogue } \\
\text { scale }\end{array}$} & \multicolumn{2}{|c|}{ Face pain scale } & \multicolumn{2}{|c|}{$\begin{array}{c}\text { Numeric rating } \\
\text { scale }\end{array}$} & \multicolumn{2}{|c|}{$\begin{array}{l}\text { Verbal rating } \\
\text { scale }\end{array}$} \\
\hline & 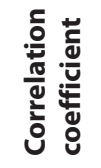 & 2 & 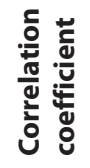 & 2 & 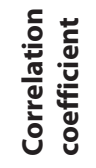 & $a$ & 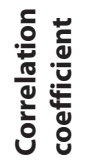 & $a$ \\
\hline Visual analogue scale & & & & & & & 0.842 & $<0.001$ \\
\hline Face pain scale & 0.866 & $<0.001$ & & & & & 0.798 & $<0.001$ \\
\hline Numeric rating scale & 0.960 & $<0.001$ & 0.897 & $<0.001$ & & & 0.860 & $<0.001$ \\
\hline Verbal rating scale & 0.842 & $<0.001$ & 0.798 & $<0.001$ & 0.860 & $<0.001$ & & \\
\hline
\end{tabular}

Spearman correlation

The participants judged the VRS and the VAS scales to be the easiest and the most difficult scale to understand, respectively. The VRS was the preferable one to be used by the participants (Table 2).

Table 2. Patient perception regarding the understanding of different pain scales - Diamantina, Minas Gerais, 2016 a 2017

\begin{tabular}{|c|c|c|}
\hline Easiest scale to understand & $\mathbf{N}$ & $\%$ \\
\hline Visual Analogue Scale (VAS) & 4 & 5.4 \\
\hline Faces Pain Scales (FPS) & 19 & 25.7 \\
\hline Numeric Rating Scale (NRS) & 12 & 16.2 \\
\hline Verbal Rating Scale (VRS) & 39 & 52.7 \\
\hline \multicolumn{3}{|l|}{ Most difficult scale to understand } \\
\hline Visual Analogue Scale (VAS) & 50 & 67.6 \\
\hline Faces Pain Scales (FPS) & 5 & 6.8 \\
\hline Numeric Rating Scale (NRS) & 17 & 23.0 \\
\hline Verbal Rating Scale (VRS) & 2 & 2.7 \\
\hline \multicolumn{3}{|l|}{ Preferable scale } \\
\hline Visual Analogue Scale (VAS) & 2 & 2.7 \\
\hline Faces Pain Scales (FPS) & 22 & 29.7 \\
\hline Numeric Rating Scale (NRS) & 8 & 10.8 \\
\hline Verbal Rating Scale (VRS) & 42 & 56.8 \\
\hline
\end{tabular}


There was no a statistically significant association between age, gender, and easiest, most difficult, and preferable scales (Table 3).

Table 3. Patient perception regarding the understanding of different types of pain scales (quantitative or categorical), according to age and gender - Diamantina, Minas Gerais, 2016 a 2017

\begin{tabular}{|c|c|c|c|c|c|c|}
\hline & \multicolumn{3}{|c|}{ Age } & \multicolumn{3}{|c|}{ Gender } \\
\hline & $\begin{array}{c}18 \text { to } 23 \\
\text { n (\%) }\end{array}$ & $\begin{array}{c}24 \text { to } 55 \\
\text { n (\%) }\end{array}$ & $\mathbf{p}$ & $\begin{array}{c}\text { Female } \\
\text { n (\%) }\end{array}$ & $\begin{array}{l}\text { Male } \\
\text { n (\%) }\end{array}$ & $\mathbf{P}$ \\
\hline \multicolumn{7}{|l|}{ Easiest scale } \\
\hline Quantitative & $8(18.2)$ & $8(26.72)$ & & $11(19.0)$ & $5(31.3)$ & \\
\hline Categorical & $36(81.8)$ & $22(73.3)$ & 0.384 & $47(81.0)$ & $11(68.8)$ & 0.291 \\
\hline \multicolumn{7}{|c|}{ Most difficult scale } \\
\hline Quantitative & $41(93.2)$ & $26(86.7)$ & & $53(91.4)$ & $14(87.5)$ & \\
\hline Categorical & $3(6.8)$ & $4(13.3)$ & 0.347 & $5(8.6)$ & $2(12.5)$ & 0.639 \\
\hline \multicolumn{7}{|c|}{ Preferable scale } \\
\hline Quantitative & $6(13.6)$ & $4(13.3)$ & & $7(12.1)$ & $3(18.8)$ & \\
\hline Categorical & $38(86.4)$ & $26(86.7)$ & 0.970 & $51(87.9)$ & $13(81.3)$ & 0.489 \\
\hline
\end{tabular}

Chi-squared test

\section{DISCUSSION}

Different pain scales are used extensively to measure clinical pain especially in dental practice ${ }^{24-26}$. Given the importance of pain assessment in the management of $\mathrm{CDH}$, a greater understanding of the relationship between multiple pain scales assessing its condition is desirable. In this study, the VAS, FPS, NRS, and VRS scales were highly correlated in patients suffering $\mathrm{CDH}$. This is maintaining the findings of a previous study that included individuals with chronic pain ${ }^{27}$. To our knowledge, no previous studies have addressed our research question across $\mathrm{CDH}$ patients. The results showed that all the pain measurement scales evaluated provide similar information about the pain reported in the $\mathrm{CDH}$, allowing the comparison between studies that used them to measure pain.

Thus, considering that the level of $\mathrm{CDH}$-related pain was similar across the scales, some other issues may impact the choice of appropriate scale in clinical practice or research. The easiest scale to understand chosen by patients in this study was VRS. Although VRS was the easiest scale, it is a low sensitivity scale once the small number of categories demands a much larger change in pain before the change shows up on the scale ${ }^{13}$. In this way, despite the ease of understanding, the use of this scale to detect sensitive changes on pain level should be used with caution. Categorical scales like VRS and FPS are preferable by older adults and children with less abstract ability ${ }^{13,28}$. The present study did not identify this preference across young patients aged from 18 to 55 years old. However, there was no participation of children and the elderly people hindering to evaluate the influence of extremes ages on the use of pain scales.

Although it presented a strong positive correlation with the other scales, the VAS was the most difficult to understand among the study participants. Similarly, in a review study aiming to explore the properties of the three used pain-rating scales (VAS, NRS, and VRS), the VAS had more practical difficulties than the others ${ }^{13}$. However, this review did not include the FPS scale in the search strategy.

Although the cognitive function and educational level of the patients were not evaluated, the strong positive correlation observed between the scales applied showed that the guidelines given before the application of the scales were well assimilated by the patients and that patients were well-consistent in their responses. However, the lack of such variables should constitute 
a limitation of this study, since the cognitive decline influences the quality of the responses of the patients regarding pain scales ${ }^{29,30}$.

The present study revealed no significant association between gender and these scales. However, most patients, regardless of gender, chose categorical scales as the easiest to understand. In this context, the use of the anchor descriptors in the quantitative scales leads to the difficulty of abstract thought, once the quantitative evaluation requires that the patients obtain an image of the painful situations in the descriptors of the scales ${ }^{31}$. On the other hand, the choice of categorical scales as easier to understand may relate to the fact they require little instruction to apply and can specify different dimensions of pain, not requiring a specific language ${ }^{3}$.

Our results are limited by the lack of data on ethnicity, educational level, and cognitive function. Future studies considering such information could refine the use of pain scales in specific contexts, regard demographic and clinical variables. Moreover, this study did not evaluate the responsiveness related to change the pain over time. It would be interesting to compare the ability of the pain scales to detect changes over time, in future work.

Pain is a subjective experience reported by the patient and the choice of the appropriate scale should be chosen according to the patient's familiarity and scales properties. Also, the chosen scale must be previously validated for the target population. The present study provides evidence that CHD patients understand the VAS, FPS, NRS, and VRS scales in a similar way and they can communicate their pain experience in clinical practice and researches using any of these tools.

\section{REFERENCES}

1. Vadivelu N, Kai AM, Kodumudi G, Babayan K, Fontes M, Burg MM. Pain and Psychology-A Reciprocal Relationship. Ochsner J. 2017;17(2):173-80. PMid:28638291.

2. Al-Harthy M, Ohrbach R, Michelotti A, List T. The effect of culture on pain sensitivity. J Oral Rehabil. 2016;43(2):81-8. http://dx.doi.org/10.1111/joor.12346. PMid:26371794.

3. Østensjø V, Moen K, Storesund T, Rosén A. Prevalence of Painful Temporomandibular Disorders and Correlation to Lifestyle Factors among Adolescents in Norway. Pain Res Manag. 2017;2017:1-10. http:// dx.doi.org/10.1155/2017/2164825. PMid:28638246.

4. Jones KR, Vojir CP, Hutt E, Fink R. Determining mild, moderate, and severe pain equivalency across painintensity tools in nursing home residents. J Rehabil Res Dev. 2007;44(2):305-14. http://dx.doi.org/10.1682/ JRRD.2006.05.0051. PMid:17551881.

5. Dantas EM, Amorim FKO, Nóbrega FJO, Dantas PMC, Vasconcelos RG, Queiroz LMG. Clinical Efficacy of Fluoride Varnish and Low-Level Laser Radiation in Treating Dentin Hypersensitivity. Braz Dent J. 2016;27(1):79-82. http://dx.doi.org/10.1590/0103-6440201602422. PMid:27007351.

6. Jena A, Shashirekha G. Comparison of efficacy of three different desensitizing agents for in-office relief of dentin hypersensitivity: A 4 weeks clinical study. J Conserv Dent JCD. 2015;18(5):389-93. http://dx.doi. org/10.4103/0972-0707.164052. PMid:26430303.

7. Torwane NA, Hongal S, Goel PBRC, Jain M, Saxena E, et al. Effect of two desensitizing agents in reducing dentin hypersensitivity: An in-vivo Comparative Clinical Trial. J Clin Diagn Res JCDR. 2013;7(9):2042-6.

8. Ritter AVL, Dias W, Miguez P, Caplan DJ, Swift EJ. Treating cervical dentin hypersensitivity with fluoride varnish: a randomized clinical study. J Am Dent Assoc 1939. 2006;137(7):1013-20.

9. Haneet RK, Vandana LK. Prevalence of dentinal hypersensitivity and study of associated factors: a crosssectional study based on the general dental population of Davangere, Karnataka, India. Int Dent J. 2016;66(1):49-57. http://dx.doi.org/10.1111/idj.12206. PMid:26582076.

10. McCann C. Preoperative analgesia for children and adolescents to reduce pain associated with dental treatment. Evid Based Dent. 2017;18(1):17-8. http://dx.doi.org/10.1038/sj.ebd.6401220. PMid:28338031.

11. Gazal G, Alharbi R, Fareed WM, Omar E, Alolayan AB, Al-Zoubi H, et al. Comparison of onset anesthesia time and injection discomfort of $4 \%$ articaine and $2 \%$ mepivacaine during teeth extractions. Saudi J Anaesth. 2017;11(2):152-7. http://dx.doi.org/10.4103/1658-354X.203017. PMid:28442952.

12. Kemp J, Despres O, Dufour A. Unreliability of the visual analog scale in experimental pain assessment: a sensitivity and evoked potentials study. Pain Physician. 2012;15(5):E693-9. PMid:22996863. 
13. Williamson A, Hoggart B. Pain: a review of three commonly used pain rating scales. J Clin Nurs. 2005;14(7):798-804. http://dx.doi.org/10.1111/j.1365-2702.2005.01121.x. PMid:16000093.

14. Goes PSA, Watt RG, Hardy R, Sheiham A. Impacts of dental pain on daily activities of adolescents aged 14-15 years and their families. Acta Odontol Scand. 2008;66(1):7-12. http://dx.doi. org/10.1080/00016350701810633. PMid:18320412.

15. Yang S-E, Park Y-G, Han K, Min J-A, Kim S-Y. Dental pain related to quality of life and mental health in South Korean adults. Psychol Health Med. 2016;21(8):981-92. http://dx.doi.org/10.1080/13548506.2015 .1098781. PMid:26456324.

16. Lima TC, Vieira-Barbosa NM, Grasielle de Sá Azevedo C, de Matos FR, Douglas de Oliveira DW, de Oliveira ES, et al. Oral Health-Related Quality of Life Before and After Treatment of Dentin Hypersensitivity With Cyanoacrylate and Laser. J Periodontol. 2017;88(2):166-72. http://dx.doi.org/10.1902/jop.2016.160216. PMid:27712461.

17. Lwanga SK, Lemeshow S. Sample size determination in health studies: a practical manual. Geneva: World Health Organization; 1991.

18. Moslemi N, Johari M, Akhoundi MSA, Zare H, Shamshiri A-R, Khorshidian A. Comparison of desensitizing efficacy of an Iranian dentifrice and a commercially available dentifrice: a randomized double-blinded controlled clinical trial. J Dent Tehran Iran. 2013;10(4):351-7. PMid:24396354.

19. Patil SA, Naik BD, Suma R. Evaluation of three different agents for in-office treatment of dentinal hypersensitivity: a controlled clinical study. Indian J Dent Res Off Publ Indian Soc Dent Res. 2015;26(1):3842. http://dx.doi.org/10.4103/0970-9290.156796. PMid:25961613.

20. Flecha OD, Azevedo CGS, Matos FR, Vieira-Barbosa NM, Ramos-Jorge ML, Gonçalves PF, et al. Cyanoacrylate versus laser in the treatment of dentin hypersensitivity: a controlled, randomized, double-masked and non-inferiority clinical trial. J Periodontol. 2013;84(3):287-94. http://dx.doi.org/10.1902/jop.2012.120165. PMid:22524329.

21. Jensen MP, Turner JA, Romano JM. What is the maximum number of levels needed in pain intensity measurement? Pain. 1994;58(3):387-92. http://dx.doi.org/10.1016/0304-3959(94)90133-3. PMid:7838588.

22. McGrath PA, Seifert CE, Speechley KN, Booth JC, Stitt L, Gibson MC. A new analogue scale for assessing children's pain: an initial validation study. Pain. 1996;64(3):435-43. http://dx.doi.org/10.1016/03043959(95)00171-9. PMid:8783307.

23. Briggs Healthcare Home. Briggs Healthcare Wong-Baker Faces Pain Rating Scale Card [Internet]. 2019 [cited 2019 March 28]. Available from: https://www.briggshealthcare.com/

24. Magraw CBL, Golden B, Phillips C, Tang DT, Munson J, Nelson BP, et al. Pain with pericoronitis affects quality of life. J Oral Maxillofac Surg Off J Am Assoc Oral Maxillofac Surg. 2015;73(1):7-12. http://dx.doi. org/10.1016/j.joms.2014.06.458. PMid:25262404.

25. Odai ED, Ehizele AO, Enabulele JE. Assessment of pain among a group of Nigerian dental patients. BMC Res Notes. 2015;8(1):8. http://dx.doi.org/10.1186/s13104-015-1226-5. PMid:26087661.

26. Pau A, Viswanath KP, Croucher R. Validation of a dental pain screening questionnaire in a semi-urban hospital setting in South India. Int Dent J. 2010;60(2):113-21. PMid:20476717.

27. Thong ISK, Jensen MP, Miró J, Tan G. The validity of pain intensity measures: what do the NRS, VAS, VRS, and FPS-R measure? Scand J Pain. 2018;18(1):99-107. http://dx.doi.org/10.1515/sjpain-2018-0012. PMid:29794282.

28. Miró J, Huguet A, Nieto R, Paredes S, Baos J. Evaluation of reliability, validity, and preference for a pain intensity scale for use with the elderly. J Pain Off J Am Pain Soc. 2005;6(11):727-35. http://dx.doi. org/10.1016/j.jpain.2005.06.005. PMid:16275596.

29. Peters ML, Patijn J, Lamé I. Pain assessment in younger and older pain patients: psychometric properties and patient preference of five commonly used measures of pain intensity. Pain Med. 2007;8(7):601-10. http://dx.doi.org/10.1111/j.1526-4637.2007.00311.x. PMid:17883744.

30. Herr K, Spratt KF, Garand L, Li L. Evaluation of the lowa pain thermometer and other selected pain intensity scales in younger and older adult cohorts using controlled clinical pain: a preliminary study. Pain Med. 2007;8(7):585-600. http://dx.doi.org/10.1111/j.1526-4637.2007.00316.x. PMid:17883743.

31. Yokobe J, Kitahara M, Matsushima M, Uezono S. Preference for different anchor descriptors on visual analogue scales among Japanese patients with chronic pain. PLoS One. 2014;9(6):e99891. http://dx.doi. org/10.1371/journal.pone.0099891. PMid:24927424. 